\title{
The central CLOCK system and the stress axis in health and disease
}

\author{
Eva N. Kassi, ${ }^{1}$ George P. Chrousos ${ }^{2}$ \\ ${ }^{1}$ Department of Biological Chemistry, ${ }^{2}$ First Department of Pediatrics, National University of Athens, Athens, Greece
}

\section{INTRODUCTION}

Optimal regulation of the hypothalamic-pituitaryadrenal (HPA) axis is critical for a successful response to any stressor as well as in non-stressful situations. At the hypothalamic-pituitary level, corticotropinreleasing hormone $(\mathrm{CRH})$ is released into the hypophyseal portal system and acts as the principal regulator of anterior pituitary adrenocorticotropic hormone $(\mathrm{ACTH})$ secretion.

Secretion of ACTH is dependent upon the binding of $\mathrm{CRH}$ to the CRH-R1 receptors of the corticotrophs, while arginine vasopresin peptide (AVP) acts as a potent synergistic factor of $\mathrm{CRH}$ exerting little ACTH secretagogue activity by itself. Recently it was shown that the stress-induced secretion of ACTH by corticotrophs is mediated through their depolarization, which is in turn mediated via intermediate conductance calcium-activated (SK4) potassium channels. ${ }^{1}$

In nonstressful situations, both CRH and AVP

Key words: ACTH, Circadian rythm, CLOCK system, Cortisol, Stress axis

Address for correspondence:

Dr E. Kassi, Department of Biological Chemistry, Medical

School, Athens University, 75 Mikras Asias Str., Goudi 11527,

Athens, Greece. E-mail: ekassi@med.uoa.gr

Received 22-11-2012, Accepted 12-02-2013 are secreted in the portal system in a circadian and highly concordant pulsatile fashion. The activity of the HPA axis is in fact characterized not only by a classic circadian rhythm, but also by an ultradian pattern of discrete pulsatile release of glucocorticoids. Glucocorticoids are the final effectors of the HPA axis. These hormones are pleiotropic and exert their effects through their ubiquitously distributed intracellular glucocorticoid receptors alpha and beta (GR $\alpha$ and GR $\beta$, respectively), both members of the nuclear receptor superfamily. ${ }^{2}$ The circadian release of $\mathrm{ACTH} /$ cortisol in their characteristic pulsatile manner appears to be controlled by one or more pace makers, whose exact location in the brain has not as yet been fully explored in humans. These diurnal variations are perturbed during daily activities like eating, sleeping, etc., while they are more greatly disrupted under stress conditions.

Dysregulation of the HPA axis in basal conditions or in response to acute or chronic (including psychosocial) stress appear to be closely related to the onset and/or the progression of several diseases, such as metabolic syndrome, depression, and autoimmune diseases.

Herein, we aim to review the current knowledge of the mechanisms that regulate ACTH and cortisol secretion under nonstressful conditions maintaining homeostasis as well as in stressful circumstances in an attempt to delineate the involvement of the 'stressresponse' component in disorders afflicting a large number of people. 


\section{ACTH SYNTHESIS}

ACTH is synthesized as part of a large precursor (241 amino acids in humans) called proopiomelanocortin (POMC). While POMC is primarily synthesized in the pituitary gland, the POMC gene is expressed in many other tissues including the hypothalamus, other brain areas, skin, testicles, duodenum, kidney, colon, liver, stomach, spleen, and heart. ${ }^{3}$ The observation that POMC-derived transcripts, as well as endorphin and corticotropin receptors, were present in immune cell lines ${ }^{4-6}$ provided the first evidence for a bidirectional communication between the immune and neuroendocrine systems. ${ }^{7}$

\section{POMC peptide hormones (Figure 1)}

POMC also contains the sequences for other hormonal peptides, including beta endorphin (beta-END), the lipotropins (LPHs), and melanocyte-stimulating hormones (MSHs), ${ }^{8}$ which are produced by subsequent tissue-specific enzymatic cleavage at pairs of basic amino acids (lys-lys or lys-arg). Prohormone convertase -1 and -2 (PC1 and $\mathrm{PC} 2$ ) are responsible for the cleavage of the POMC prohormone.

Beta-endorphin has potent opioid activity in the central nervous system, but its function in peripheral plasma is still unknown. However, there is strong evidence that beta-endorphin participates in immunological processes, like macrophage differentiation, ${ }^{9}$ as well as in platelet activity. ${ }^{10}$

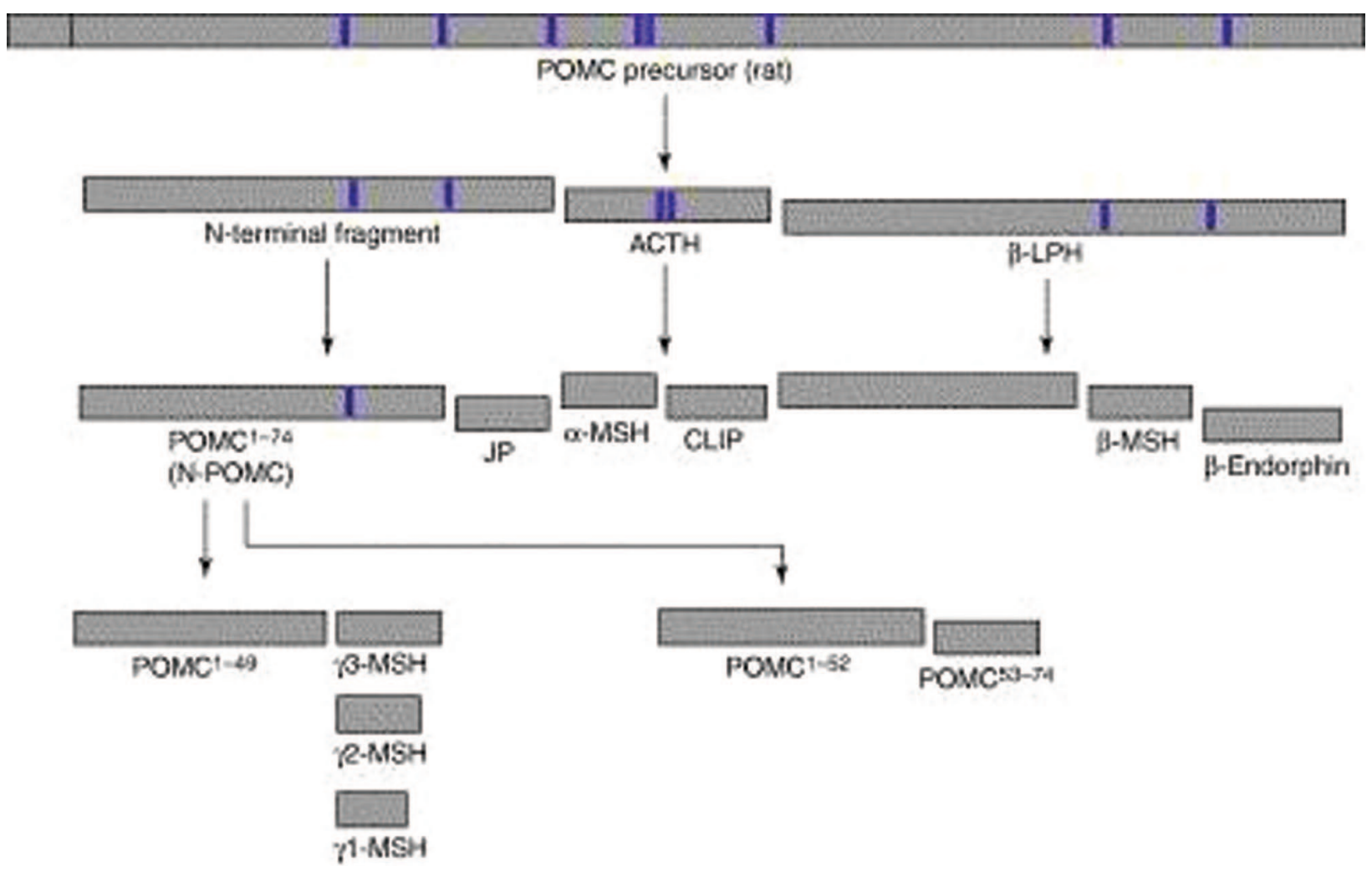

Figure 1. Processing of pro-opiomelanocortin (POMC) to various bioactive peptides in the adenohypophysis. POMC is first split into a long N-terminal fragment, adrenocorticotropin $(\mathrm{ACTH})$, and $\beta$-lipotropin $(\beta$-LPH). Particularly in the intermediate lobe, ACTH can be further converted to melanocyte-stimulating hormone ( $\alpha$-MSH) and corticotropin-related intermediate-lobe peptide (CLIP). $\beta$-LPH generates $\beta$-endorphin and $\beta$-MSH. The N-terminal fragment is further processed to a smaller N-terminal fragment, $\mathrm{N}$ POMC (POMC1-74 in rat and mouse, POMC1-76 in human and POMC1-80 in pig) and 'joining peptide' (JP). From its C-terminal end, $\gamma$-MSH peptides can be generated. In the adrenal cortex POMC1-74 can be converted into POMC1-52 and an N-terminally truncated $\gamma 3$-MSH (POMC53-74) by a specific protease located at the plasma membrane. POMC1-74 has a complex structure. It is glycosylated on Thr45 and Asn65 and there are two disulfide bridges, one between Cys2 and Cys24 and one between Cys8 and Cys20. Adapted from Denef C, 2003 Trends Endocrinol Metab 14:188-195. 
Although their physiologic function is not fully elucidated, the lipotropins, and in particular beta $\mathrm{LPH}$, are potent stimulators of lipolysis, exerting their systemic actions through adipocytes. Lipotropins may also play a putative role in hematopoiesis by activating bone marrow adipocytes to function as hematopoietic factors. ${ }^{11}$

MSHs ( $\alpha$-, $\beta$-, and $\gamma$-melanocyte-stimulating hormones) have potent anti-inflammatory, anti-pyretic, neuroregenerative, and anorexigenic effects in the brain. Alpha-MSH plays a role in the regulation of metabolic functions, with its production and maturation processes being regulated according to the metabolic state of the organism. ${ }^{12,13}$

POMC synthesis is stimulated by $\mathrm{CRH}$, which is synthesized by neurons in the parvocellular (small cell) division of the hypothalamic paraventricular nuclei. ${ }^{14}$ Their axons project to the median eminence, where $\mathrm{CRH}$ is secreted into the hypophysial portal blood. CRH acts by binding to the cell surface $\mathrm{CRH}$ 1 receptor, which is a G-protein coupled receptor activating adenylyl cyclase, thereby stimulating the cyclic AMP-dependent protein kinase A (PKA) signal transduction pathway. $\mathrm{CRH}$ is also able to modulate the processing of $\mathrm{POMC}$ via changes in $\mathrm{PC}-1$ expression levels. ${ }^{15}$ Unlike CRH, AVP does not by itself, or in synergism with CRH, stimulate POMC gene transcription. ${ }^{16}$

\section{REGULATION OF ACTH SECRETION}

ACTH secretion is regulated by multiple hormones. $\mathrm{CRH}$ is probably the most important ACTH secretagogue..$^{17}$ AVP can potentiate the action of $\mathrm{CRH}$, though on its own it is a weak stimulator of ACTH secretion. ${ }^{18-20}$

AVP enhances adenylyl cyclase action, by binding to the $\mathrm{V} 3$ receptor (known as the $\mathrm{V} 1 \mathrm{~b}$ receptor), ${ }^{21,22}$ thus activating the phospholipase $\mathrm{C}$ - phosphatidylinositol pathway, which mobilizes intracellular calcium stores and diacylglycerol. Diacyloglycerol activates in turn the phospholipid/calcium-dependent protein kinase C. ${ }^{23}$ However, it is important to note that activation of the parvocellular vasopressin system has an important role in the adaptation of the HPA axis to experimentally-induced chronic stress of arthritis in rodents, while variations in hypothalamic AVP may be the main regulators of circadian rhythmicity in humans. ${ }^{24}$

Apart from CRH and AVP, several other hormones, neuropeptides, and cytokines have been shown to participate in the regulation of ACTH release in vivo and/or in vitro. Ghrelin, vasoactive intestinal peptide (VIP), peptide histidine isoleucine (PHI), excitatory amino acids, catecholamines, angiotensin II, galanin, and serotonin have been shown to stimulate the release of ACTH either directly or indirectly through CRH. ${ }^{25-30}$ Interestingly, drugs that affect neurotransmission and are widely used for treating various diseases can interfere with the HPA axis, either stimulating it (serotonin receptor agonists, dopaminergic agonists and antagonists, tricyclic antidepressants) or inhibiting it (serotonin antagonists, GABAergic agonists such as benzodiazepines and valproic acid, alpha 2 receptor agonists such as clonidine, selective noradrenaline reuptake inhibitors such as reboxetine, as well as antipsychotic drugs which antagonize serotonin, dopamine, and histamine receptors).$^{30}$ Leptin is also expressed in the central branch of the HPA axis, where it can regulate $\mathrm{CRH}$ and ACTH secretion acting in an autocrine-paracrine manner. Studies have demonstrated that leptin can both inhibit and enhance the HPA axis depending on the species. ${ }^{31}$ It is of note that leptin-deficient humans are characterized by elevated basal cortisol and ACTH levels and a disturbed diurnal rhythm, both of which indicate an inhibitory effect of leptin on the HPA axis. In the same line, hypoleptinemia in Anorexia Nervosa is associated with an up-regulated HPA axis. ${ }^{32,33}$ However, according to recent studies, in healthy humans (with fluctuations of leptin levels within the physiologic range), regulation of the HPA axis appears to be independent of leptin. ${ }^{34}$ Cytokines, such as interferons (IFN-alpha, IFN-gamma), interleukins (IL-1, IL-2, IL-6), and tumor necrosis factor -alpha (TNF- $\alpha$ ), stimulate the HPA axis at all three levels (hypothalamus, pituitary, and adrenal cortex) after acute or chronic administration. Thus, immunotherapy for cancer or chronic hepatitis can increase ACTH and cortisol levels. ${ }^{30,35}$ Interestingly, Navarra et al were the first to demonstrate in rats that IL-6 and IL-1 exert an enhancing effect on the HPA by acutely stimulating the secretion of $\mathrm{CRH}$ from the 
hypothalamus at concentrations known to occur in human plasma and cerebrospinal fluid. ${ }^{36}$

Prolactin (PRL), growth hormone (GH), and growth hormone releasing hormone $(\mathrm{GHRH})$ are also implicated in the positive regulation of the hypothalamic pituitary-adrenal (HPA) axis. Whether PRL acts directly on pituitary ACTH production is controversial; however, it has been suggested that at the hypothalamic level it can stimulate ERK/MAPK activity on CRH gene transcription in the paraventricular nucleus (PVN), whereas it exerts indirect inhibitory actions through modulation of neural pathways to the PVN. ${ }^{37-39}$ GH-releasing peptide (GHRP)-2, which has a strong $\mathrm{GH}$ stimulating activity, is also known to activate the HPA axis. Data suggest that GHRP-2 may directly stimulate ACTH secretion in patients with hypothalamic-pituitary disorders. ${ }^{40}$

Leukemia inhibitory factor is able to stimulate POMC synthesis and ACTH secretion. ${ }^{41}$ Cortisol inhibits both CRH and AVP synthesis and release, mediated via genomic processes through the glucocorticoid and mineralocorticoid receptor signaling system activation; as a result, cortisol deficiency results in increased AVP release, which contributes to the water retention and hyponatremia that occur in patients with adrenal insufficiency. ${ }^{42}$ On the other hand, high levels of glucocorticoids (either exogenous or endogenous) cause corticotroph cell degeneration. This glucocorticoid negative feedback occurs at two more levels: cortisol inhibits POMC transcription as well as ACTH release induced by CRH and AVP. It appears that a rapid non-genomic glucocorticoid receptor-mediated inhibitory effect, specifically targeted to ACTH secretion from pituitary corticotrophs, also exists. ${ }^{43}$ Opioid peptides, oxytocin, preproTRH (178-199), atrial natriuretic peptide (ANP), and somatostatin may also inhibit ACTH secretion..$^{30,44-46}$ Endocannabinoids appear to negatively regulate basal and stimulated ACTH release at multiple levels of the hypothalamic-pituitaryadrenal axis. ${ }^{47}$ This conserved ability of endocannabinoid signaling to regulate HPA axis activity may represent one of the mechanisms by which inhibition of cannabinoid receptor type 1 (CB1) receptor signaling (i.e. rimonabant) can contribute to the incidence of depression in humans. ${ }^{48}$

\section{ACTH ACTION}

When secreted, ACTH is a 39-amino acid peptide that stimulates secretion of cortisol, androgens (mainly dehydroepiandrosterone [DHEA] and DHEA sulfate), and acutely and to a lesser extent aldosterone from the adrenal cortex. It is important to note that the first 24 amino-terminal amino acids are those that determine the biological activity of the ACTH molecule. The residue 25-39 is important for stability as it increases the half-life of the molecule. The plasma half-life of ACTH depends upon how it is measured. Bioactivity disappears from the plasma in vivo with a half-life of 4 to 10 minutes, whereas immunoreactive ACTH may disappear more or less rapidly, according to which part of the molecule is recognized by the antibody used in the ACTH assay. ${ }^{49}$

Once secreted, ACTH enters the systemic circulation and binds to specific high affinity receptors (ACTH receptors) located on the surface of adrenocortical cells. Upon ligand binding, the ACTH receptor, which is a Gs-coupled protein receptor, undergoes conformation changes that stimulate adenyl cyclase, leading in turn to an increase in intracellular cAMP and subsequent activation of protein kinase $\mathrm{A}$. The cAMP-protein kinase (PKA) transduction pathway is the main regulator of genes involved in glucocorticoid synthesis. Although the exact targets of PKA have yet to be fully determined, several transcription factors, such as Steroidogenic Factor-1 (SF-1), adrenal specific protein (ASP), specificity protein 1 (Sp-1), and polypyrimidine tract-binding protein-associated splicing factor (PSF), have been shown to be required for conveying cAMP-dependent transcription. ${ }^{50,51}$

\section{CHARACTERISTICS OF CORTISOL SECRETION}

There are four major characteristics of cortisol secretion in normal subjects. These are 1) pulsatile secretion (ultradian pulsatility - ultradian rhythms are recurrent periods or cycles repeated throughout a 24-hour circadian day, 2) circadian rhythm (circadian rhythms are changes that follow an endogenous 24hour cycle, responding primarily to light and darkness), 3) stress-induced secretion, and 4) negative feedback inhibition by glucocorticoids. 


\section{Ultradian pulsatility}

Like other anterior pituitary hormones, ACTH is secreted in brief episodic bursts, occurring approximately every one to two hours, ${ }^{52}$ that cause rapid rises in plasma ACTH and serum cortisol concentrations, followed by a rapid fall in plasma ACTH and a slower fall in serum cortisol, due to the slower clearance of the cortisol from plasma.

The diurnal rhythm of cortisol secretion results from ACTH secretory episodes of greater amplitude in the morning hours. ${ }^{53-56}$ It has been shown that the amplitude - and not the frequency - of the secretory episodes increases after three to five hours of sleep, reaching a maximum in the last few hours before and the hour after awakening. As a consequence, peak values of plasma cortisol are mostly observed during the first 30 to 45 minutes after awakening. ${ }^{57}$ The amplitude of the secretory episodes declines throughout the morning and is minimal in the evening. ${ }^{55}$ It is the changes in pulse amplitude, and to a lesser extent frequency, that make up the circadian rhythm of cortisol.

There is tighter synchrony between ACTH and cortisol secretory dynamics during the late night, when secretion is greatest, than during the day. ${ }^{58} \mathrm{In}$ one report, plasma ACTH and serum cortisol levels rose more steeply within a 30-minute interval immediately after awakening than in the several hours before awakening. A dissociation between ACTH and cortisol seems to become detectable at the end of the sleep phase, with the ACTH showing a trend towards a steeper rise, as compared to cortisol levels, in the last hour before awakening. ${ }^{59} \mathrm{With}$ increasing age, there is increasing asynchrony of ACTH and cortisol secretion. As a result, plasma ACTH and serum cortisol concentrations are highest at about the time of waking in the morning, fall irregularly during the day, are low in the late afternoon and evening, and reach their nadir an hour or two after beginning sleep. Eating a high-protein meal at noon and much less in the early evening has been shown to cause additional secretory episodes (lunch cortisol peak) ${ }^{60}$ It should be noted here that in young (18 to 35 year old) and older (60 to 72 years old) men, the overall daily pattern of serum cortisol concentrations is similar, but peak serum cortisol concentrations occur almost three hours earlier in the morning in older men, and their daily mean serum cortisol concentration is slightly higher, especially in the evening hours. ${ }^{61}$

In healthy adults, adrenal and pituitary response to endogenous ACTH pulses is associated with age, body mass index (BMI), and gender. Gender markedly affects how age influences ACTH efficacy (increased and decreased, respectively, in women and men), while age and BMI together modulate adrenal sensitivity (both negatively) and ACTH potency (both positively).$^{62}$ A correlation was reported in one study between peaks of cortisol secretion and an electroencephalographic (EEG) index of alertness (activity) during daytime wakefulness, with serum cortisol pulses lagging about 10 minutes behind the EEG activity. ${ }^{63}$ Cortisol secretion lagged about 10 minutes behind ACTH secretion, which was not measured, so ACTH secretion presumably occurs almost simultaneously with the increased brain activation. In one sleep study, cortisol secretion was inversely correlated with slow wave sleep, with cortisol changes preceding the changes in EEG (delta waves) by 10 minutes. The two activities appeared to be driven by independent generators. ${ }^{64}$ Rapid eye movement (REM) sleep was associated with a decrease in cortisol secretory rates preceding REM onset. According to the same study, a single rule determines the association between cortisol and the NREM-REM sleep cycles: delta wave activity cannot develop unless corticotropic activity is low and never builds up in a period of high secretory activity. Vgontzas et al studying the effect of sleep deprivation on the pulsatility of cortisol during the post deprivation day showed a significant reduction of pulse amplitude as well as of the 24-hour and daytime peak area, but not of the pulse frequency. Slow wave sleep remained negatively correlated with cortisol. ${ }^{65}$ The pulsatility of glucocorticoid secretion is an important factor in determining the responsivity of the HPA axis to stress ${ }^{66}$ and the transcriptional responses of glucocorticoid responsive genes. ${ }^{67} \mathrm{~A}$ recent study by McMaster et al. suggests that ultradian cortisol pulsatility exerts important effects on target cell gene expression and phenotype; pulsatile cortisol can cause a significant reduction in cell survival compared to continuous exposure of the same cumulative dose, due to increased apoptosis. ${ }^{68}$

The mechanisms for ultradian HPA activity are 
still unclear. Nevertheless, animal studies suggest that pulsatile $\mathrm{CRH}$ is not the signal for the ultradian ACTH rhythm. ${ }^{69}$ In fact, relatively simple feed-forward and feedback interactions between the pituitary and adrenal cortex may be sufficient to account for the ultradian pulsatility in the absence of an ultradian source from a suprapituitary site. These oscillations will of course be modified by the gain from the $\mathrm{CRH}$ and AVP input to the pituitary, which in turn can be modified by the activity of suprapituitary feedback mediated through both the glucocorticoid receptor and the mineralocorticoid receptor. ${ }^{70}$ The factors that contribute to the pattern of cortisol secretion are of great interest and the possibility of genetic implication was studied by analyzing monozygotic and dizygotic pairs of male normal twins. Genetic control is found for the timing of the cortisol nadir and for the proportion of overall temporal variability associated with pulsatility, while strong environmental effects are identified for both the 24-h mean and the timing of the morning acrophase. ${ }^{71}$

\section{Circadian rhythm}

Humans, like most other organisms, have an endogenous pacemaker that generates a circadian (Lat. "circa-diem", meaning "about one day") rhythm in several physiologic processes, including hypothalamicpituitary-adrenal secretion. ${ }^{72}$

The diurnal fluctuations arise from signal communication between the hypothalamic suprachiasmatic nucleus and the adrenal gland and consist of both the autonomic nervous system and endocrine regulation of the HPA axis. ${ }^{73}$ The timing of the circadian rhythm is synchronized to the solar day by the dark-light shift (the Zeitgeber, or "time-giver"), which, under normal conditions, is a reflection of the sleep-wake pattern. ${ }^{74}$ As long as it is synchronized, the circadian rhythm is a diurnal rhythm. In totally blind subjects (i.e. those with no dark-light Zeitgeber), the diurnal rhythm becomes free-running, with a periodicity of 24.5 to 25 hours. ${ }^{73}$ However, some subjects who are functionally blind because of retinal degeneration maintain a normal circadian rhythm. ${ }^{75,76}$

The age that the cortisol rhythm normally first appears is still unclear. Some reports state that the acquisition of this rhythm occurs between the ages of two to three months ${ }^{77,78}$ to 12 months, while other reports state that rhythms are not established until about three years of age..$^{79} \mathrm{~A}$ twin study suggests that environment may play a greater role than genetics in the timing of the onset of the cortisol circadian rhythm. ${ }^{80}$ In elderly subjects, the rhythm shifts about three hours earlier, as noted above. ${ }^{59,81}$ This shift may be due to earlier awakening. Alternatively, the earlier time of awakening may be dictated by the shift in cortisol rhythm, or both may change as a result of some other factor. ${ }^{82}$

The normal pattern of cortisol secretion is resistant to acute change. It is not altered by prolonged bed rest, continuous feeding, three to five days of fasting, ${ }^{61,83}$ two to three days of sleep deprivation. ${ }^{84}$ Four days of sleep deprivation, especially later night sleep loss (3 to $6 \mathrm{AM}$ ), is associated with a decrease in morning serum cortisol levels that return to normal after one night of recovery sleep. ${ }^{85-88}$

After a major time-shift, as an example, after longdistance jet travel, it may take one to two weeks for the rhythm to readjust completely. ${ }^{89}$ Exposure to bright light after such a change can speed the readjustment and perhaps lessen the symptoms of jet lag. However, ordinary room light of about 180 lumens is sufficient to reset the circadian pacemaker, ${ }^{90,91}$ while a newer study indicated that the human circadian pacemaker is highly sensitive even to typical room light intensities during the late biological night, with about 100 lux evoking half of the effects observed with light 10 times as bright. ${ }^{92}$ However, it should be noted that the guidelines for best possible dosing and treatment are scarce. Administration of melatonin the day before and after a major time-shift may also help readjust the rhythm. ${ }^{3}$ Exogenous melatonin can shift sleep time and hormones and increase sleep propensity, particularly during times of day when endogenous melatonin production is low, ${ }^{94}$ whereas the question of appropriate dose, timing, and formulation of melatonin for the adjustment of circadian rhythms has not yet been resolved. ${ }^{55}$ Currently, the development of agents that are selective for melatonin receptors, such as ramelteon, agomelatine, and tasimelteon, provides an opportunity to further elucidate the actions of melatonin and its receptors and to develop novel treatments for patients suffering from circadian rhythm sleep disorders, including people affected by jet lag and those who work at night as well as early- 
riser workers. ${ }^{96} \mathrm{It}$ is noteworthy that two randomized controlled multicentre trials for tasimelteon (VEC162) have already confirmed its efficacy for treatment of transient insomnia associated with shifted sleep and wake time. ${ }^{97}$

\section{The CLOCK (circadian locomotor output cycle kaput) system (Figure 2)}

As mentioned above, human beings live under the strong influence of light/dark cycles created by the day/night changes due to the 24- hour rotation of the earth. A highly conserved ubiquitous molecular "clock", namely circadian CLOCK system, ensures the acclimation to every new set of environmental conditions. Actually, the CLOCK creates internal circadian rhythmicity upon the influence of light/ dark information and synchronizes their physical activities, such as food intake, energy metabolism, rest and sleep.

There are two major components of the CLOCK system that generate the circadian rhythm: the central and the peripheral. The central component is located in the suprachiasmatic nuclei (SCN) of the hypothalamus and acts as a "master" clock under the potent influence of light/dark input from the eyes. ${ }^{98}$ Light/dark information travels via the retinohypothalamic tract from the retina, specifically from the retina ganglion cells, which are intrinsically photosensitive ${ }^{76}$ to the suprachiasmatic nucleus where

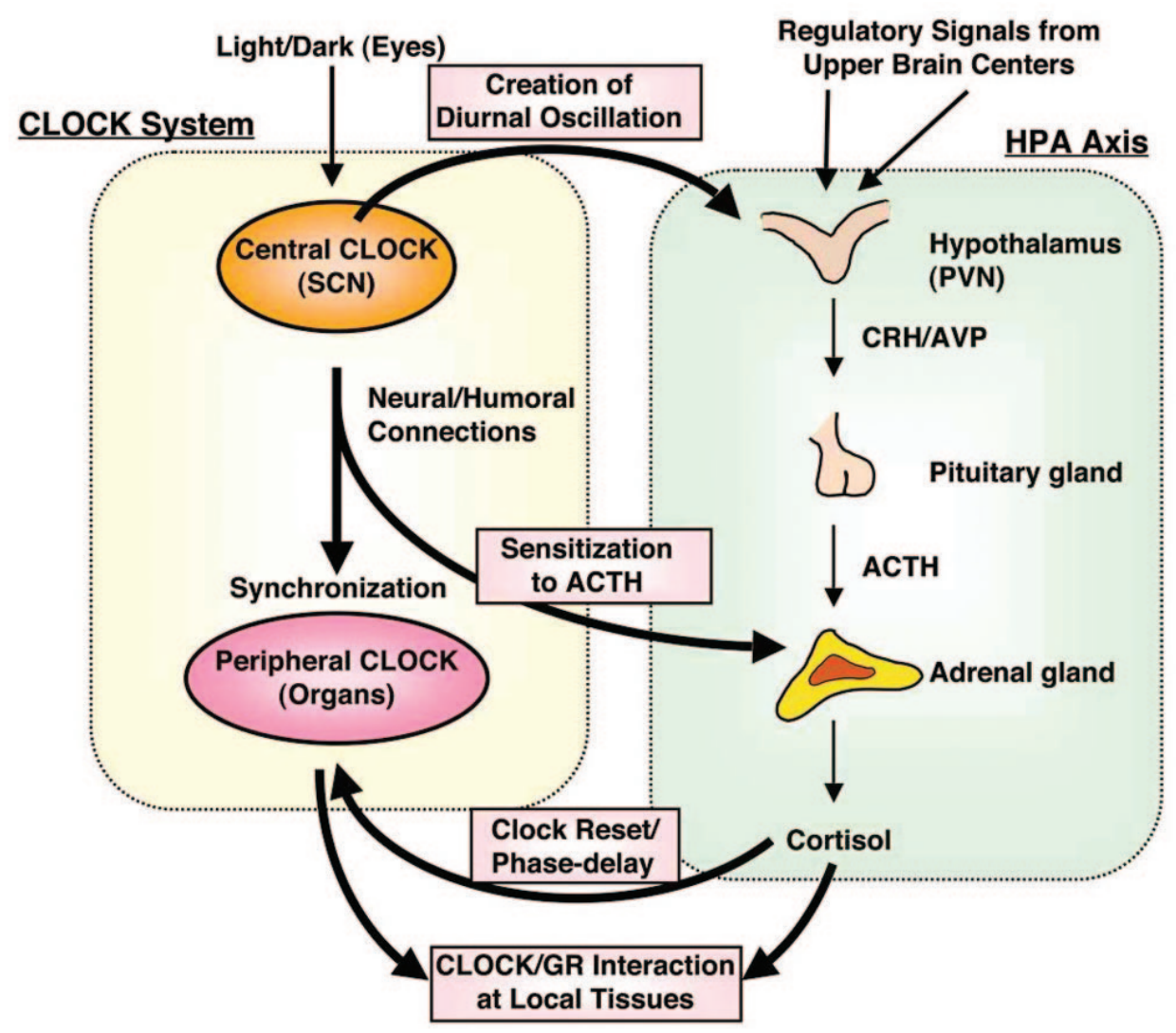

Figure 2. The light-activated central CLOCK located in the SCN orchestrates the daily rhythmic release of glucocorticoids by influencing the activity of the HPA axis through efferent connections from the SCN to the CRH/AVP-containing neurons of the PVN. Additionally, splachnic nerve innervation to the adrenal medulla via the SCN-ANS axis also contributes to circadian GC secretion and resets the adrenal local clock through modulating adrenal sensitivity to ACTH by the action of epinephrine and possible other mediators. Secreted glucocorticoids in turn reset and phase-delay circadian rhythm of the peripheral CLOCKs by stimulating the expression of several CLOCK-related genes; this is especially important for temporal adjustment of the body's activity against stress. The peripheral CLOCKs also regulate glucocorticoid effect in local tissues through interaction between Clock/Bmal1 and GR, providing a local counter-regulatory feedback loop to the effect of central CLOCK on the HPA axis. Adapted from Nader N, Chrousos GP, Kino T, 2010 Trends Endocrinol Metab 21: 277-286. 
efferent neurons (1) transfer timing information to other parts of the central nervous system such as the PVN, medial preoptic area (MPA), and dorsomedial nucleus (DMH) of the hypothalamus and the pineal gland, and (2) affect the autonomic nervous system (sympathetic and parasympathetic) and regulate the secretion of pituitary hormones and melatonin, which in turn control basic functions of the body like sleep, food intake, and body temperature. ${ }^{99,100}$ The peripheral components of the CLOCK system are found in all organs and tissues including the brain beyond the SCN. ${ }^{99,101}$

Both central and peripheral CLOCK systems have almost the same transcriptional regulatory machinery for generating intrinsic circadian rhythms. ${ }^{99,102} \mathrm{~A}$ central role in this machinery is played by the clock (circadian locomotor output cycle kaput) transcription factor and its heterodimer partner bmal1(brainmusclearnt-like protein 1), which belong to the basic helixloop-helix PAS superfamily of transcription factors. The clock gene was first identified in 1994 by Takahashi and colleagues in a search for genes that regulate circadian rhythms in mammals. ${ }^{103}$

During the day, interaction between clock and bmal1 leads to transcription activation of the per (period 1,2,3) and cry (cryptochrome 1,2) genes, resulting in high levels of these transcripts. The resulting per and cry proteins heterodimerize, translocate to the nucleus, and interact with the clock-bmal1 complex to inhibit their own transcription. During the night, the per-cry repressor complex is degraded and clock-bmaill can then activate a new cycle of transcription. ${ }^{104}$ The entire cycle takes approximately 24 hours to complete and results from a combination of transcriptional and post-translational negative feedback loops, where protein products of the per and cry genes periodically suppress their own expression. The post-translational modification and degradation of clock proteins are critical steps that define circadian periodicity of the CLOCK, ${ }^{105}$ while rhythmic alterations in adenosine 3',5'-monophosphate (cAMP) signaling appear to determine central CLOCK properties of amplitude, phase, and period. ${ }^{106}$ The central CLOCK system synchronizes the circadian rhythm of peripheral CLOCK systems through both humoral and neural connections that have not yet been clearly defined. ${ }^{100}$ Therefore, destruction of the central CLOCK system abolishes synchronization of the peripheral CLOCK system in different organs, while circadian rhythm of each peripheral CLOCK is still maintained, suggesting that peripheral CLOCK systems have conditional autonomy from the central CLOCK system. As noted above, circulating glucocorticoid (GC) levels are tightly regulated and fluctuate naturally in a circadian fashion, reaching their peak in the early morning and their nadir in the late evening in humans with the purpose of helping adjust the physical activities such as motivational behaviors, food intake, energy metabolism, rest and sleep to the regular periodicity of day/night changes. ${ }^{107}$ We now know that the light-activated central CLOCK system located in the suprachiasmatic nuclei ( $\mathrm{SCN}$ ) orchestrates this daily rhythmic release of GCs by influencing the activity of the HPA axis through efferent connections from the SCN to the CRH/AVP-containing neurons of the PVN. ${ }^{108}$

Additionally, splanchnic nerve innervation to the adrenal medulla via the SCN-ANS (autonomic nervous system) axis also contributes to circadian GC secretion and resets the adrenal local CLOCK system through modulating adrenal sensitivity to ACTH by the action of epinephrine. ${ }^{109}$

Reciprocally, the HPA axis exerts its own influence on the circadian rhythm of the CLOCK system through GCs. GCs seems to affect the peripheral CLOCKs in almost all organs and tissues, but not the central CLOCK in the SCN, since SCN does not express GR, which mediates the GC effects. ${ }^{110}$ In particular, GCs reset the peripheral CLOCK systems by influencing the expression of several clock-related genes (such as per1 and per2) in peripheral tissues (like liver, kidney, heart) and in some brain areas such as the amygdala in a GRE-dependent manner. ${ }^{111-113}$

On the other hand, it has recently been shown that peripheral CLOCK-mediated circadian acetylation of the human GR may serve as a target-tissue, gene-specific counter-regulatory mechanism to the actions of diurnally fluctuating cortisol, decreasing tissue sensitivity to GCs in the morning and increasing it at night. ${ }^{114}$

Altogether, it could be concluded that the CLOCK and HPA systems crosstalk with each other at peripheral target tissues but not centrally where the 
master CLOCK maintains its intrinsic circadian rhythm independently of HPA activation by external or internal stimuli. This crosstalk is mediated through the GC-GR complex. It is important to note that the HPA axis influences virtually all organs and tissues through its end-effectors glucocorticoids, which are necessary for the maintenance of many important biologic activities, such as the homeostasis of the CNS, the cardiovascular system, intermediary metabolism, and the immune/inflammatory reaction. ${ }^{115}$

\section{Stress-induced secretion of cortisol}

Acute physical or psychological stress activates the hypothalamic-pituitary-adrenal axis, resulting in increased plasma ACTH and cortisol concentrations. Stress is defined as a state in which homeostasis is actually threatened or perceived to be so, while homeostasis is re-established by a complex repertoire of behavioral and physiological adaptive responses of the organism.

Acute physical or psychological stress activates the stress system. The core stress system consists of the CRH system and the locus ceruleus/norepinephrine (LC-NE) systems and their peripheral limbs, the HPA axis, and the autonomic nervous systems. The principal peripheral effectors are glucocorticoids, which are regulated by the HPA axis, and the catecholamines norepinephrine and epinephrine, which are regulated by the systemic and adrenomedullary sympathetic nervous systems. Stress mediators, apart from the classic neuroendocrine hormones of the stress system, also include several other neurotransmitters, cytokines, and growth factors that regulate both basal and threatened homeostasis. ${ }^{115,116}$ Thus, stress exerts its effects by stimulating the hypothalamus to release multiple ACTH secretagogues, with CRH and AVP being the most important. ${ }^{117,118}$ IL-6 also enhances the hypothalamic-pituitary-adrenal axis response to inflammation and other stressors in both adults and children/adolescents. ${ }^{119-122}$

Physical stresses include severe trauma, burns or illness, major surgery, inflammation, fever, hypoglycemia, hypotension, exercise, and cold exposure. ${ }^{1223-126}$ The pituitary adrenal response to these stresses appears to be dose-dependent, being proportional to the extent of a burn ${ }^{123}$ or the intensity of exercise..$^{126}$ Pretreatment with glucocorticoids blocks the response to minor stress, but may not alter the response to major stress. ${ }^{127,128}$

\section{Surgery}

One of the most potent activators of the HPA axis is surgery. The regulation of the HPA axis in the operative and perioperative period of major surgical procedures is necessary for successful adaptation to surgical stress. Studies generally show that at the time of incision as well as during surgery the HPA is moderately activated, especially during reversal of anesthesia and after extubation, whereby plasma ACTH levels are increased and are associated with elevated serum cortisol concentrations. Right after, ACTH declines rapidly to normal levels, while cortisol levels decrease slowly, reaching high normal values 48 to 72 hours after the procedure. ${ }^{125,127,129}$ This has been confirmed in coronary artery bypass graft operations, although not by all studies, ${ }^{130}$ where basal and stimulated cortisol levels have been correlated with severity of stress, peaking shortly after extubation and being similar to levels during other major surgical procedures and critical illness. ${ }^{131,132}$

Studies demonstrate that this principally occurs through cytokine regulation of the HPA axis primarily by direct or indirect stimulation of hypothalamic CRH, especially by IL-1, IL- 6 , and TNF- $\alpha$, and also by directly affecting the pituitary and adrenal glands. ${ }^{133}$ It is of interest that in a subpopulation of patients exposed to cardiopulmonary bypass (CPB), this systemic reaction can propagate a huge pro-inflammatory response, similar to that seen in sepsis and termed SIRS (systemic inflammatory response syndrome).

Comparison of the responses of the stress hormones, cortisol, ACTH, CRH to elective conventional and laparoscopic surgery, fails to reveal any significant difference. ${ }^{134}$

Of note, opiate drugs can reduce the plasma ACTH and serum cortisol responses to surgery ${ }^{125,133}$ via blunting the pituitary ACTH response to $\mathrm{CRH}$ and possibly acting centrally to inhibit secretion of ACTH secretagogues. ${ }^{127,135,136}$

\section{Hypoglycemia}

Hypoglycemia activates the medial basal hypothalamus ${ }^{137}$ and stimulates CRH release but has no direct effect on ACTH secretion. 
Hypoglycemia also increases AVP, epinephrine, and norepinephrine concentrations. ${ }^{138}$ AVP probably plays a role in the pituitary response to hypoglycemia, but peripheral catecholamines are not involved. ${ }^{139,140}$

Current data show that a gradual induction of hypoglycemia can produce a cortisol response with an onset corresponding with the time blood glucose concentrations have reached approximately $59 \mathrm{mg} /$ $\mathrm{dL}(3.3 \mathrm{mmol} / \mathrm{L}$, much higher than $40 \mathrm{mg} / \mathrm{dL}[2.2$ $\mathrm{mmol} / \mathrm{L}]$, which is the aim of a standard insulin tolerance test), peaking approximately three hours after the start of insulin infusion. ${ }^{141}$

\section{Fever and inflammation}

Fever, caused by systemic infection or by pyrogen administration (which both stimulate prostaglandins and Nitric Oxide [NO] release), is a potent stimulus of ACTH and cortisol secretion. ${ }^{142}$

Studies in rats indicate an opposite action of prostaglandins generated by cyclooxygenase and nitric oxide synthesized by inducible nitric oxide synthase (iNOS) in the lipopolysaccharide (LPS)-induced HPAresponse, with prostaglandins stimulating the $\mathrm{ACTH}$ response to endotoxin and NO inhibiting it. ${ }^{143,144}$

Further investigation regarding the role of prostaglandins in the HPA axis response to LPS indicates that induced prostaglandin synthesis, via Cyclooxygenase -2 (Cox-2), contributes to the delayed HPA axis activation, whereas constitutive prostaglandin synthesis, via Cox-1, is involved in the early HPA response. ${ }^{145}$ Infection or exposure of mononuclear leukocytes to bacterial endotoxin causes release of IL-1 and IL-6, both of which stimulate hypothalamic CRH secretion; IL-2, which stimulates ACTH secretion indirectly ${ }^{146,147}$ and possibly directly; ${ }^{148}$ and tumor necrosis factor-alpha, which stimulates ACTH secretion directly. ${ }^{149,150} \mathrm{IL}-1$-beta and pyrogen also increase the hypothalamic and anterior pituitary expression of leukemia-inhibitory factor, a member of the IL- 6 family and a potent ACTH secretagogue. ${ }^{151,152}$ The specific roles for $\mathrm{CRH}$ and leukemia inhibitory factor (LIF) in regulating the HPA axis during inflammation remain under investigation. Recent studies demonstrate that central CRH appeared to be more critical in mediating ACTH release in response to shock or alcohol than to LPS treatment. ${ }^{153}$ This observation is also supported by data showing that CRH knockout animals have nearly normal HPA axis reaction to inflammatory challenges. ${ }^{118}$ Additionally, animals with LIF deficiency have markedly lower POMC and ACTH responses to inflammation induced by a high dose of LPS, ${ }^{154}$ while exogenous LIF injection restores pituitary POMC expression in LIFKO (LIF knockout) animals. ${ }^{155}$ In vitro and animal studies show that LIF significantly potentiates the effects of CRH on POMC transcription. It seems that $\mathrm{CRH}$ is required for rapid increase of ACTH synthesis and release in response to any nonspecific stressful challenge, while LIF is important for maintaining a sustained activation of the HPA axis during the inflammatory process. Nevertheless, double-knockout mice (CRH/LIFKO) still demonstrate a robust $\mathrm{ACTH}$ and corticosterone response to inflammation, probably due to the profuse TNF- $\alpha$, IL-1 $1 \beta$, and IL- 6 activation observed in the hypothalamus and pituitary of these animals. ${ }^{156}$

Studies evaluating the adrenal response to critical illness yield conflicting results. Excessive release of $\mathrm{ACTH}$ and cortisol characterizes the initial phase of critical illness as a result of increased $\mathrm{CRH}$ secretion and cytokine production. As a general rule, the degree of activation of the axis is proportional to the stress. However, the degree of elevation in serum cortisol concentration is not always correlated linearly with the illness severity.

In fact, some studies demonstrate that patients with the highest cortisol levels have the highest mortality as well. ${ }^{129}$ However, during prolonged critical illness, the ACTH and cortisol responses may become separated - high cortisol levels persist despite suppression of ACTH suggesting that cortisol secretion is being stimulated by alternative pathways - other than hypothalamic $\mathrm{CRH}$, such as AVP, ANP, endothelin, and a variety of cytokines, especially IL-6. ${ }^{129,157}$

Severe critical illness can be characterized by "relative" corticosteroid insufficiency. This inadequacy in corticosteroid activity in relation to the severity of the patient's illness has been characterized as CIRCI: critical illness-related corticosteroid insufficiency. ${ }^{158}$

The lower thresholds for stress-elevated basal cortisol concentrations vary greatly among various studies. It has been proposed that cortisol levels $<414 \mathrm{nmol} / \mathrm{L}$ are strongly indicative of adrenal insufficiency. ${ }^{157-159}$ However, the best test currently available for estab- 
lishing the diagnosis may be the $1-\mu \mathrm{g}$ corticotrophin stimulation test, in which cortisol levels are measured 30 minutes after stimulation, with a level of less than $690 \mathrm{nmol}$ per liter or an increment over baseline of less than $250 \mathrm{nmol} / \mathrm{L}$ per liter representing an inadequate adrenal response. ${ }^{160}$

Mechanisms of adrenal suppression in critical illness remain as yet largely unclear. Among other candidates, cytokines and adipokines which are derived from fat cells may affect the normal synthesis and release of ACTH and cortisol as well as the activity of glucocorticoid receptors. It has been established that TNF- $\alpha$ and peptides like corticostatins derived from immune cells may compete with ACTH on its receptor, negatively influencing adrenal cortisol secretion and inducing tissue resistance to glucocorticoids. ${ }^{160-162}$

Studies investigating the prognostic value of measuring baseline and cosyntropin stimulated serum cortisol lead to conflicting results. ${ }^{163-165}$

Interestingly, the Corticosteroid Therapy for Septic Shock (CORTICUS) study, investigating the use of i.v. hydrocortisone in patients with septic shock, concluded that hydrocortisone did not significantly improve survival in patients who did not respond to cosyntropin. ${ }^{166}$

Labor also represents a condition of stress in humans. Maternal ACTH and cortisol levels increase during normal labor and drop at about four days postpartum; however, maternal ACTH and cortisol levels at this stage are not correlated. ${ }^{167}$

\section{Chronic stress}

Apart from acute stress, chronic stress is also characterized by a dysregulation of the HPA axis. Chronic hypersecretion of stress mediators, such as cortisol, in individuals with a vulnerable background may lead to behavioral consequences such as melancholic depression, anorexia nervosa, panic disorder, post-traumatic stress disorder in children, alcoholism, as well as somatic consequences such as central obesity/metabolic syndrome, diabetes mellitus, and osteopenia/osteoporosis. ${ }^{168-170}$

It is well known that glucocorticoids directly cause insulin resistance of peripheral target tissues in proportion to their levels and to the particular target tissue's sensitivity to these hormones. Over time, cumulative chronic or intermittent stress may lead to development of progressive accumulation of visceral fat with concurrent loss of lean body mass and hence worsening manifestations of the metabolic syndrome such as dyslipidemia, chronic low-grade inflammation, blood hypercoagulation, arterial hypertension, and/or diabetes mellitus type 2. Similarly, through decreased bone formation and/or increased bone resorption, osteopenia or osteoporosis may ensue. ${ }^{120,168,169,171}$

Specifically, the increase of adipose tissue and its consequent infiltration by macrophages both promote the secretion of pro-inflammatory cytokines (such as TNF- $\alpha$ and IL-6) and hormones (adipokines such as leptin, resistin), while inhibiting the secretion of adiponectin into the circulation. These pro-inflammatory adipokines activate a generalized chronic inflammatory state in the body. ${ }^{172,173}$

Interestingly, TNF- $\alpha$ and IL- 6 stimulate the HPA axis, as has already been discussed, while they both, in conjunction with the increased resistin and decreased adiponectin, promote insulin resistance and exert atherogenic effects. A recent clinical study by Kazakou et al. confirmed that the HPA axis in patients with metabolic syndrome is more active, as evidenced by the higher cortisol levels after the overnight dexamethasone suppression test and by the higher ACTH levels during the oral glucose tolerance test. ${ }^{174}$

In turn, the activated HPA axis and the resulting hypercortisolemia contribute further to the visceral fat accumulation, indicating that a vicious cycle may develop..$^{175}$

In addition, increased levels of both IL-6 and cortisol lead to suppression of other major endocrine axes, such as the gonadal axis. The combination of lower levels of gonadal steroids and increased levels of cortisol promotes bone resorption, osteopenia, and osteoporosis. ${ }^{176}$

Hyperactivation or hypoactivation of the HPA axis has been associated with increased susceptibility of the individual to psychiatric, infectious, allergic, and autoimmune diseases. Glucocorticoids directly inhibit the production of type 1 cytokines, such as IL-12, IL-2, TNF- $\alpha$, and INF- $\gamma$, that enhance cellular immunity and Th1 formation and conversely favor the 
production of type 2 cytokines, such as IL-10, IL-4, IL-13, that induce humoral immunity and T-helper 2 (Th2) activity. ${ }^{177}$ Thus, during an immune challenge, stress causes an adaptive Th1 to Th2 shift in order to protect the tissues from the potentially destructive actions of the pro-inflammatory type 1 cytokines and other products of activated macrophages. The homeostatic role of stress-induced Th2 shift against overshooting of cellular immunity often complicates pathologic conditions where either cellular immunity is beneficial (e.g. carcinogenesis, infections) or humoral immunity is deleterious (e.g. allergy, autoimmune diseases). ${ }^{178}$

On the other hand, there are a number of pathologies characterized by decreased activity of the HPA axis, among them atypical/seasonal depression, chronic fatigue syndrome, postpartum blues or depression, systemic autoimmune diseases such as Sjogren's syndrome, and fibromyalgia. ${ }^{167,179-181}$ Some evidence demonstrates that these abnormalities are related to a "CRH deficient" phenotype characterized by blunted and delayed plasma ACTH responses, which are associated with small rather than exaggerated cortisol responses to $\mathrm{CRH}{ }^{182,183}$ Interestingly, other pathogenetic mechanisms such as decreased glucocorticoid sensitivity and a re-activation of hypothalamic ACTH secretagogue peptides have recently been proposed as the pathophysiological mechanisms involved in fibromyalgia and postpartum blues, respectively. ${ }^{184-185}$

Since dysregulation of the HPA axis in basal conditions or in response to acute or chronic (including psychosocial) stress appear to be closely and possibly causally related with the onset and/or the progression of several diseases, the need to develop markers for assessing the individual's HPA axis activity becomes of great interest. In this context, cortisol-awakening response (CAR) and the Trier Social Stress Test (TSST) were developed to assess HPA axis basal activity and HPA axis stress reactivity, respectively. CAR is a consistent response of the HPA axis to morning awakening that is distinct from the circadian rise in HPA axis activity in the morning hours. ${ }^{186}$ Although the stability of the CAR over time is clearly limited (see above), it seems to be superior to alternative protocols that are comparably easy to assess. Moreover, the moderate stability simply reflects (in addition to measurement errors) the adaptability of the HPA axis to respond sensitively to numerous internal and external stimuli.

TSST consists of a brief preparation period (three minutes) and a test period in which the subject delivers a free speech (mock job interview over five minutes) and performs mental arithmetic (a serial subtraction task over five minutes) in front of an audience. ${ }^{187}$ In recent years there have been a growing number of studies showing significantly altered CARs and TSSTs in various health conditions, including psychopathology. ${ }^{188,189}$ However, whether both tests can be used as a diagnostic tool for the prediction of disease susceptibility and symptom severity and/or for monitoring the efficacy of interventions remains to be investigated.

\section{Glucocorticoid negative feedback}

Another important characteristic of cortisol secretion is the feedback inhibition of ACTH secretion. This occurs at the pituitary and hypothalamic levels, the hippocampus, and perhaps at higher centers. In the pituitary, glucocorticoids inhibit ACTH secretion acutely and ACTH synthesis more slowly. It has been shown that glucocorticoids inhibit POMC gene and $\mathrm{CRH}$ receptor gene transcription, thus resulting in reductions in POMC mRNA concentrations, POMC synthesis, and the number of CRH receptors. ${ }^{8,190-192}$ This happens either through negative-GREs that are present at the POMC gene promoter or through interactions between NGFI-B/Nur77 Orphan Nuclear Receptors and GR. ${ }^{193,194}$

Regarding its action at higher centers, glucocorticoids decrease CRH and AVP mRNA and peptide stores in the hypothalamic paraventricular nuclei. ${ }^{195,196}$ Of note, there is a differential effect of glucocorticoids on the expression of CRH and AVP mRNA in response to acute stress: CRH expression is unaffected, but AVP expression is markedly inhibited. ${ }^{197}$

Glucocorticoids block the stimulatory effects of $\mathrm{CRH}$ and AVP on pituitary ACTH secretion and POMC synthesis ${ }^{198}$ through interaction of the GC-GR complex with members of the superfamily of Nur77 nuclear receptors. ${ }^{193}$ In CRH-deficient (knockout) mice, adrenalectomy increases POMC gene expression in the pituitary, but not ACTH secretion unless CRH is replaced. ${ }^{199}$ Glucocorticoids suppress SR-BI 
expression, thus exerting another negative feedback action by reducing the adrenal gland synthesis of glucocorticoids..$^{200,201}$ As a consequence of these actions of glucocorticoids, plasma ACTH concentrations are high in patients with Addison's disease and are low in patients with Cushing's syndrome caused by a cortisol-secreting adrenal tumor or exogenous glucocorticoid administration.

Glucocorticoid feedback inhibition of ACTH secretion appears to consist of at least two phases, as has been shown in animal models. ${ }^{202}$ Fast feedback occurs within seconds to minutes and is proportional to the rate of increase in serum glucocorticoid concentrations rather than the absolute concentration. Newer data support the hypothesis that glucocorticoid-induced fast feedback inhibition of the HPA axis is mediated by a nongenomic signaling mechanism (membraneGR) that involves endocannabinoid signaling at the level of the PVN, as the dexamethasone fast feedback response is blocked by the cannabinoid CB1 receptor antagonist AM-251. ${ }^{203}$ Slow (delayed) feedback occurs in hours to days and is proportional to the dose, potency, and duration of action of exogenously administered glucocorticoids and is therefore related to the absolute serum glucocorticoid concentration. This action is mediated through nuclear glucocorticoid receptors. Although any glucocorticoid can suppress ACTH secretion, none can inhibit ACTH-stimulated cortisol production. ${ }^{204}$ The degree of suppression depends on the dose, potency, and duration of action of the glucocorticoid, as well as the time of its administration. The shorter the interval between the administration of glucocorticoid and the normal early morning peak of ACTH secretion, the greater the suppressive effect of the glucocorticoid. The duration of suppression is increased by higher doses and longer-acting glucocorticoids. After withdrawal of chronic administration of high doses of glucocorticoid, suppression of the hypothalamic-pituitary-adrenal axis persists for weeks or even months.

\section{CONCLUSION}

The secretion of ACTH, and therefore of cortisol, is regulated by hormonal and neural interactions among the hypothalamus, pituitary, and adrenal glands. CRH is probably the most important ACTH secretagogue, while AVP alone is a weak stimulator of ACTH secretion, but it potentiates the action of $\mathrm{CRH}$ in vivo and in vitro. Moreover, inputs from higher brain centers can exert their effects upon the CRH secretion. Pulsatility of glucocorticoid secretion is an important factor in determining the responsivity of the HPA axis to stress and the transcriptional responses of glucocorticoid responsive genes. The CLOCK system (with its central and peripheral components), located in the SCN, orchestrates the circadian rhythm by influencing the activity of the HPA axis. Reciprocally, the HPA axis exerts its own influence on the circadian rhythm of the CLOCK system through glucocorticoids. Acute and chronic stress is characterized by a dysregulation of the HPA axis, with either increased or decreased activity.

Dysregulation of the HPA axis in basal conditions or in response to acute or chronic (including psychosocial) stress appear to be closely (and possibly causally) related to the onset and/or the progression of several diseases like central obesity/ metabolic syndrome, diabetes mellitus, osteopenia/ osteoporosis, depression, and autoimmune diseases. The development of markers for assessing the individual's HPA axis activity is today of great interest. Moreover, a better understanding of the mechanisms that regulate ACTH and cortisol secretion (which is a major component of the stress system) will help us to delineate the implication of the 'stress-response' component in various diseases of western civilization.

\section{REFERENCE}

1. Nicolaides NC, Galata Z, Kino T, Chrousos GP, Charmandari E, 2010 The human glucocorticoid receptor: molecular basis of biologic function. Steroids 75: 1-12.

2. Liang Z, Chen L, McClafferty H, et al, 2011 Control of hypothalamic pituitary-adrenal stress axis activity by the intermediate conductance calcium activated potassium channel, SK4. J Physiol 589: 5965-5986.

3. DeBold CR, Nicholson WE, Orth DN, 1988 Immunoreactive proopiomelanocortin (POMC) peptides and POMClike messenger ribonucleic acid are present in many rat nonpituitary tissues. Endocrinology 122: 2648-2657.

4. Lyons PD, Blalock JE, 1997 Pro-opiomelanocortin gene expression and protein processing in rat mononuclear leukocytes. J Neuroimmunol 78: 47-56.

5. Galin FS, LeBoeuf RD, Blalock JE, 1991 Corticotropinreleasing factor upregulates expression of two truncated pro-opiomelanocortin transcripts in murine lymphocytes. 
J Neuroimmunol 31: 51-58.

6. Murao K, Sato M, Imachi H, et al, 1998 Expression of truncated proopiomelanocortin gene transcript in human leukemia cell lines. Endocr J 45: 399-405.

7. Blalock JE, 1999 Proopiomelanocortin and the immuneneuroendocrine connection. Ann N Y Acad Sci 885: 161-172.

8. Lundblad JR, Roberts JL, 1988 Regulation of proopiomelanocortin gene expression in pituitary. Endocr Rev 9: 135-158.

9. Hagi K, Inaba K, Sakuta H, Muramatsu S, 1995 Enhancement of murine bone marrow macrophage differentiation by beta-endorphin. Blood 86: 1316-1321.

10. Tirelli A, Guastafierro S, Annunziata S, Guariglia R, Coppola L, 2001 Effects of beta-endorphin and metenkephalin on platelet activity. Am J Hematol 68: 1701.

11. Halabe BA, 2008 The role of lipotropins as hematopoietic factors and their potential therapeutic use. Exp Hematol 36:7 52-754.

12. Bertolini A, Tacchi R, Vergoni AV, 2009 Brain effects of melanocortins. Pharmacol Res 59: 13-47.

13. D’Agostino G, Diano S, 2010 Alpha-melanocyte stimulating hormone:production and degradation. J Mol Med (Berl) 88: 1195-1201.

14. Swanson LW, Sawchenko PE, Rivier J, Vale WW, 1983 Organization of ovine corticotropin-releasing factor immunoreactive cells and fibers in the rat brain: an immunohistochemical study. Neuroendocrinology 36: 165-186.

15. Kageyama K, Suda T, 2009 Role and action in the pituitary corticotroph of corticotropin-releasing factor (CRF) in the hypothalamus. Peptides 30:810-816.

16. Levin N, Blum M, Roberts JL, 1989 Modulation of basal and corticotrophin releasing factor-stimulated proopiomelanocortin gene expression by vasopressin in rat anterior pituitary. Endocrinology 125: 2957-2966.

17. Vale W, Spiess J, Rivier C, Rivier J, 1981 Characterization of a 41-residue ovine hypothalamic peptide that stimulates secretion of corticotropin and beta endorphin. Science 213: 1394-1397.

18. 18 Antoni FA, 1993 Vasopressinergic control of pituitary adrenocorticotropin secretion comes of age. Front Neuroendocrinol 14: 76-122.

19. Vale W, Vaughan J, Smith M, Yamamoto G, Rivier J, Rivier C, 1983 Effects of synthetic ovine corticotropinreleasing factor, glucocorticoids, catecholamines, neurohypophysial peptides, and other substances on cultured corticotropic cells. Endocrinology 113: 1121-1131.

20. DeBold CR, Sheldon WR, DeCherney GS, et al, 1984 Arginine vasopressin potentiates adrenocorticotropin release induced by ovine corticotropin-releasing factor. J Clin Invest 73: 533-538.

21. de Keyzer Y, Auzan C, Lenne F, et al, 1994 Cloning and characterization of the human V3 pituitary vasopressin receptor. FEBS Lett 356: 215-220.

22. Sugimoto T, Saito M, Mochizuki S, Watanabe Y, Hashimoto S, Kawashima H, 1994 Molecular cloning and functional expression of a cDNA encoding the human
V1b vasopressin receptor. J Biol Chem 269: 27088-27092.

23. Bilezikjian LM, Blount AL, Vale WW, 1987 The cellular actions of vasopressin on corticotrophs of the anterior pituitary: Resistance to glucocorticoid action. Mol Endocrinol 1: 451-458.

24. Chowdrey HS, Larsen PJ, Harbuz MS, et al 1995 Evidence for arginine vasopressin as the primary activator of the HPA axis during adjuvant-induced arthritis.Br J Pharmacol 116: 2417-2424.

25. Arvat E, Maccario M, Di Vito L, et al, 2001 Endocrine activities of ghrelin, a natural growth hormone secretagogue (GHS), in humans: comparison and interactions with hexarelin, a nonnatural peptidyl GHS, and GH-releasing hormone. J Clin Endocrinol Metab 86: 1169-1174.

26. Alexander LD, Sander LD, 1995 Involvement of vasopressin and corticotrophin releasing hormone in VIP- and PHI-induced secretion of ACTH and corticosterone. Neuropeptides 28: 167-173.

27. Jezova D, 2005 Control of ACTH secretion by excitatory amino acids: functional significance and clinical implications. Endocrine 28: 287-294.

28. Saavedra JM, Sanchez-Lemus E, Benicky J, 2011 Blockade of brain angiotensin II AT1 receptors ameliorates stress, anxiety, brain inflammation and ischemia: Therapeutic implications. Psychoneuroendocrinology 36: 1-18.

29. Tortorella C, Neri G, Nussdorfer GG, 2007 Galanin in the regulation of the hypothalamic-pituitary-adrenal axis. Int J Mol Med19: 639-647.

30. Ambrogio AG, Pecori GF, Cavagnini F, 2008 Drugs and HPA axis. Pituitary 11: 219-229.

31. Malendowicz LK, Rucinski M, Belloni AS, Ziolkowska A, Nussdorfer GG, 2007 Leptin and the regulation of the hypothalamic-pituitary-adrenal axis. Int Rev Cytol 263: 63-102.

32. Ozata M, Ozdemir IC, Licinio J, 1999 Human leptin deficiency caused by a missense mutation: multiple endocrine defects, decreased sympathetic tone, and immune system dysfunction indicate new targets for leptin action, greater central than peripheral resistance to the effects of leptin, and spontaneous correction of leptin-mediated defects. J Clin Endocrinol Metab 84: 3686-3695.

33. Richard D, Lin Q, Timofeeva E, 2002 The corticotropinreleasing factor family of peptides and CRF receptors: their roles in the regulation of energy balance. Eur $\mathrm{J}$ Pharmacol 440: 189-197.

34. Chan JL, Matarese G, Shetty GK, et al, 2006 Differential regulation of metabolic, neuroendocrine, and immune function by leptin in humans. Proc Natl Acad Sci USA 103: 8481-8486.

35. Besedovsky HO, del Rey A, 1996 Immune-neuro-endocrine interactions: facts and hypotheses. Endocr Rev 17: 64-102.

36. Navarra P, Tsagarakis S, Faria MS, Rees LH, Besser GM, Grossman AB, 1991 Interleukins-1 and -6 stimulate the release of corticotropin-releasing hormone-41 from rat 
hypothalamus in vitro via the eicosanoid cyclooxygenase pathway. Endocrinology 128: 37-44.

37. Blume A, Torner L, Liu Y, Subburaju S, Aguilera G, Neumann ID, 2009 Prolactin activates mitogen-activated protein kinase signaling and corticotrophin releasing hormone transcription in rat hypothalamic neurons. Endocrinology 150: 1841-1849.

38. Korbonits M, Kaltsas G, Perry LA, et al, 1999 The growth hormone secretagogue hexarelin stimulates the hypothalamo-pituitary-adrenal axis via arginine vasopressin. J Clin Endocrinol Metab 84: 2489-2495.

39. Perras B, Schultes B, Schwaiger R, et al, 2002 Growth hormone-releasing hormone facilitates hypoglycemiainduced release of cortisol. Regul Pept 110: 85-91.

40. Kimura T, Shimatsu A, Arimura H, et al, 2010 Concordant and discordant adrenocorticotropin (ACTH) responses induced by growth hormone-releasing peptide-2 (GHRP2), corticotropin-releasing hormone (CRH) and insulin 782 induced hypoglycemia in patients with hypothalamopituitary disorders: evidence for direct ACTH releasing activity of GHRP-2. Endocr J 57: 639-644.

41. Schwartz J, Revskoy S, Redei E, Clifton V, Smith R, Cherny R, 2002 Corticotrophs and peptides. Arch Physiol Biochem 110: 146-153.

42. De Kloet ER, Vreugdenhil E, Oitzl MS, Joels M, 1998 Brain corticosteroid receptor balance in health and disease. Endocr Rev 19: 269-301.

43. Russell GM, Henley DE, Leendertz J,et al, 2010 Rapid glucocorticoid receptor mediated inhibition of hypothalamic-pituitary-adrenal ultradian activity in healthy males. J Neurosci 30: 6106-6115.

44. Legros JJ, Chiodera P, Demey-Ponsart E, 1982 Inhibitory influence of exogenous oxytocin on adrenocorticotropin secretion in normal human subjects. J Clin Endocrinol Metab 55: 1035-1039.

45. Pecori GF, Pesce S, Maroni P, et al, 2010: Inhibitory effect of prepro-thyrotrophin-releasing hormone (178-199) on adrenocorticotrophic hormone secretion by human corticotroph tumours. J Neuroendocrinol 22: 294-300.

46. Demiralay C, Jahn H, Kellner M, Yassouridis A, Wiedemann K, 2010 Influence of exogenous atrial natriuretic peptide on the nocturnal hypothalamic-pituitary adrenal axis and sleep in healthy men. Psychoneuroendocrinology 35: 1438-1445.

47. Hill MN, Tasker JG, 2012 Endocannabinoid signaling, glucocorticoid-mediated negative feedback, and regulation of the hypothalamic-pituitary-adrenal axis. Neuroscience 204: 5-16.

48. Hill MN, Gorzalka BB, 2009: Impairments in endocannabinoid signaling and depressive illness. JAMA 301: 1165-1166.

49. Besser GM, Orth DN, Nicholson WE, Byyny RL, Abe K, Woodham JP, 1971 Dissociation of the disappearance of bioactive and radioimmunoreactive ACTH from plasma in man. J Clin Endocrinol Metab 32: 595-603.

50. Sewer MB, Waterman MR, 2003 ACTH modulation of transcription factors responsible for steroid hydroxylase gene expression in the adrenal cortex. Microsc Res Tech 61: 300-307.

51. Sewer MB, Waterman MR, 2001 Insights into the transcriptional regulation of steroidogenic enzymes and StAR. Rev Endocr Metab Disord 2: 269-274.

52. Young EA, Abelson J, Lightman SL, 2004 Cortisol pulsatility and its role in stress regulation and health. Front Neuroendocrinol 25: 69-76.

53. Krieger DT, Allen W, Rizzo F, Krieger HP, 1971 Characterization of the normal temporal pattern of plasma corticosteroid levels. J Clin Endocrinol Metab 32: 266-284.

54. Weitzman ED, Fukushima D, Nogeire C, Roffwarg H, Gallagher TF, Hellman L, 1971 Twenty-four hour pattern of the episodic secretion of cortisol in normal subjects. J Clin Endocrinol Metab 33: 14-22.

55. Veldhuis JD, Iranmanesh A, Johnson ML, Lizarralde G, 1990 Amplitude, but not frequency, modulation of adrenocorticotropin secretory bursts gives rise to the nyctohemeral rhythm of the corticotropic axis in man. J Clin Endocrinol Metab 71: 452-463.

56. Wallace WH, Crowne EC, Shalet SM, et al, 1991 Episodic ACTH and cortisol secretion in normal children. Clin Endocrinol (Oxf) 34: 215-221.

57. Wust S, Wolf J, Hellhammer DH, Federenko I, Schommer N, Kirschbaum C, 2000 The cortisol awakening response - normal values and confounds. Noise Health 2: 79-88.

58. Roelfsema F, Pincus SM, Veldhuis JD, 1998 Patients with Cushing's disease secrete adrenocorticotropin and cortisol jointly more asynchronously than healthy subjects. J Clin Endocrinol Metab 83: 688-692.

59. Wilhelm I, Born J, Kudielka BM, Schlotz W, Wust S, 2007 Is the cortisol awakening rise a response to awakening? Psychoneuroendocrinology 32: 358-366.

60. Slag MF, Ahmad M, Gannon MC, Nuttall FQ, 1981 Meal stimulation of cortisol secretion: a protein induced effect. Metabolism 30: 1104-1108.

61. Bergendahl M, Iranmanesh A, Mulligan T, Veldhuis JD, 2000 Impact of age on cortisol secretory dynamics basally and as driven by nutrient-withdrawal stress. J Clin Endocrinol Metab 85: 2203-2214.

62. Veldhuis JD, Iranmanesh A, Roelfsema F, et al, 2011 Tripartite control of dynamic ACTH-cortisol dose responsiveness by age, body mass index, and gender in 111 healthy adults. J Clin Endocrinol Metab 96: 2874-2881.

63. Chapotot F, Gronfier C, Jouny C, Muzet A, Brandenberger $\mathrm{G}, 1998$ Cortisol secretion is related to electroencephalographic alertness in human subjects during daytime wakefulness. J Clin Endocrinol Metab 83: 4263-4268.

64. Gronfier C, Chapotot F, Weibel L, Jouny C, Piquard F, Brandenberger G, 1998 Pulsatile cortisol secretion and EEG delta waves are controlled by two independent but synchronized generators. Am J Physiol 275: E94-100.

65. Vgontzas AN, Mastorakos G, Bixler EO, Kales A, Gold PW, Chrousos GP, 1999 Sleep deprivation effects on the activity of the hypothalamic-pituitary adrenal and growth axes: potential clinical implications. Clin Endocrinol (Oxf) 51: 205-215. 
66. Lightman SL, Wiles CC, Atkinson HC, et al, 2008 The significance of glucocorticoid pulsatility. Eur J Pharmacol 583: $255-262$

67. Stavreva DA, Wiench M, John S, 2009 Ultradian hormone stimulation induces glucocorticoid receptor-mediated pulses of gene transcription. Nat Cell Biol 11: 1093-1102.

68. McMaster A, Jangani M, Sommer P, et al, 2011 Ultradian cortisol pulsatility encodes a distinct, biologically important signal. PLoS One 6:e15766.

69. Engler D, Pham T, Liu JP, Fullerton MJ, Clarke IJ, Funder JW, 1990 Studies of the regulation of the hypothalamicpituitary-adrenal axis in sheep with hypothalamic-pituitary disconnection. II. Evidence for in vivo ultradian hypersecretion of proopiomelanocortin peptides by the isolated anterior and intermediate pituitary. Endocrinology 127: 1956-1966.

70. Walker JJ, Terry JR, Lightman SL, 2010 Origin of ultradian pulsatility in the hypothalamic-pituitary-adrenal axis. Proc Biol Sci 277: 1627-1633.

71. Linkowski P, Van Onderbergen A, Kerkhofs M, et al 1993 Twin study of the 24-h cortisol profile: evidence for genetic control of the human circadian clock. Am J Physiol 264: E173-181.

72. Szafarczyk A, Ixart G, Malaval F, Nouguier-Soule J, Assenmacher I, 1979 Effects of lesions of the suprachiasmatic nuclei and of p-chlorophenylalanine on the circadian rhythms of adrenocorticotrophic hormone and corticosterone in the plasma, and on locomotor activity of rats. J Endocrinol 83: 1-16.

73. Chrousos GP, 1998 Ultradian, circadian, and stressrelated hypothalamic pituitary-adrenal axis activity-a dynamic digital-to-analog modulation. Endocrinology 139: 437-440.

74. Moore-Ede MC, Czeisler CA, Richardson GS, 1983 Circadian timekeeping in health and disease. Part 1. Basic properties of circadian pacemakers. N Engl J Med 309: 469-476.

75. Orth DN, Besser GM, King PH, Nicholson WE, 1979 Free-running circadian plasma cortisol rhythm in a blind human subject. Clin Endocrinol (Oxf) 10: 603- 617.

76. Berson DM, Dunn FA, Takao M, 2002 Phototransduction by retinal ganglion cells that set the circadian clock. Science 295: 1070-1073.

77. de WC, Zijl RH, Buitelaar JK 2003 Development of cortisol circadian rhythm in infancy. Early Hum Dev 73: 39-52.

78. Mantagos S, Moustogiannis A, Vagenakis AG 1998 Diurnal variation of plasma cortisol levels in infancy. $\mathrm{J}$ Pediatr Endocrinol Metab 11: 549-553.

79. Glotzbach SF, Edgar DM, Boeddiker M, Ariagno RL, 1994 Biological rhythmicity in normal infants during the first 3 months of life. Pediatrics 94: 482-488.

80. Custodio RJ, Junior CE, Milani SL, Simoes AL, de Castro M, Moreira AC, 2007 The emergence of the cortisol circadian rhythm in monozygotic and dizygotic twin infants: the twin-pair synchrony. Clin Endocrinol (Oxf) 66: 192-197.
81. Sherman B, Wysham C, Pfohl B, 1985 Age-related changes in the circadianrhythm of plasma cortisol in man. J Clin Endocrinol Metab 61: 439-443.

82. Czeisler CA, Dumont M, Duffy JF, et al, 1992 Association of sleep-wake habits in older people with changes in output of circadian pacemaker. Lancet 340: 933-936.

83. Vance ML, Thorner MO, 1989 Fasting alters pulsatile and rhythmic cortisol release in normal man. J Clin Endocrinol Metab 68: 1013-1018.

84. Krieger DT 1979 Rythms in CRF, ACTH, and corticosteroids. In: Endocrine Rhythms, Raven Press, New York.

85. Spiegel K, Leproult R, L'Hermite-Baleriaux M, Copinschi G, Penev PD, Van CE, 2004 Leptin levels are dependent on sleep duration: relationships with sympathovagal balance, carbohydrate regulation, cortisol, and thyrotropin. J Clin Endocrinol Metab 89: 5762-5771.

86. Vgontzas AN, Bixler EO, Lin HM, et al, 2001 Chronic insomnia is associated with nyctohemeral activation of the hypothalamic-pituitary-adrenal axis: clinical implications. J Clin Endocrinol Metab 86: 3787-3794.

87. Deuschle M, Schweiger U, Weber B, et al, 1997 Diurnal activity and pulsatility of the hypothalamus-pituitaryadrenal system in male depressed patients and healthy controls. J Clin Endocrinol Metab 82: 234-238.

88. Wu H, Zhao Z, Stone WS, Huang L, et al, 2008 Effects of sleep restriction periods on serum cortisol levels in healthy men. Brain Res Bull 77: 241-245.

89. Desir D, Van CE, Fang VS, et al, 1981 Effects of "jet lag" on hormonal patterns. I. Procedures, variations in total plasma proteins, and disruption of adrenocorticotropincortisol periodicity. J Clin Endocrinol Metab 52: 628-641.

90. Boivin DB, Duffy JF, Kronauer RE, Czeisler CA, 1996 Dose-response relationships for resetting of human circadian clock by light. Nature 379: 540-542.

91. Boivin DB, Czeisler CA, 1998 Resetting of circadian melatonin and cortisol rhythms in humans by ordinary room light. Neuroreport 9: 779-782

92. Zeitzer JM, Khalsa SB, Boivin DB, et al, 2005 Temporal dynamics of late night photic stimulation of the human circadian timing system. Am J Physiol Regul Integr Comp Physiol 289: R839-R844.

93. Sack RL, Lewy AJ, Hughes RJ, 1998 Use of melatonin for sleep and circadian rhythm disorders. Ann Med 30: 115-121.

94. Rajaratnam SM, Dijk DJ, Middleton B, et al, 2003 Melatonin phase-shifts human circadian rhythms with no evidence of changes in the duration of endogenous melatonin secretion or the 24-hour production of reproductive hormones. J Clin Endocrinol Metab 88: 4303-4309.

95. Arendt J, Skene DJ, 2005 Melatonin as a chronobiotic. Sleep Med Rev 9: 25-39.

96. Ferguson SA, Rajaratnam SM, Dawson D, 2010 Melatonin agonists and insomnia. Worthnoting, two randomised controlled multicentre trials for tasimelteon (VEC-162) have already confirmed its efficacy for treatment of transient insomnia associated with shifted sleep and wake time. Expert Rev Neurother 10: 305-318. 
97. Rajaratnam SM, Polymeropoulos MH, Fisher DM, et al, 2009 Melatonin agonist tasimelteon (VEC-162) for transient insomnia after sleep time shift: two randomised controlled multicentre trials. Lancet 373: 482-491.

98. Nader N, Chrousos GP, Kino T, 2010 Interactions of the circadian CLOCK system and the HPA axis. Trends Endocrinol Metab 21: 277-286.

99. Takahashi JS, Hong HK, Ko CH, McDearmon EL, 2008 The genetics of mammalian circadian order and disorder: implications for physiology and disease. Nat Rev Genet 9: 764-775.

100. Kalsbeek A, Palm IF, La Fleur SE, et al, 2006 SCN outputs and the hypothalamic balance of life. J Biol Rhythms 21: 458-469.

101. Ko CH, Takahashi JS, 2006 Molecular components of the mammalian circadian clock. Hum Mol Genet 15 Spec No 2: R271-R277.

102. Hastings M, O’Neill JS, Maywood ES, 2007 Circadian clocks: regulators of endocrine and metabolic rhythms. J Endocrinol 195: 187-198.

103. Vitaterna MH, King DP, Chang AM, et al, $1994 \mathrm{Mu}-$ tagenesis and mapping of a mouse gene,Clock, essential for circadian behavior. Science. 264: 719-725.

104. Lee C, Etchegaray JP, Cagampang FR, Loudon AS, Reppert SM, 2001 Posttranslational mechanisms regulate the mammalian circadian clock. Cell 107: 855-867.

105. Gallego M, Virshup DM, 2007 Post-translational modifications regulate the ticking of the circadian clock. Nat Rev Mol Cell Biol 8: 139-148.

106. O’Neill JS, Maywood ES, Chesham JE, Takahashi JS, Hastings MH, 2008 cAMP-dependent signaling as a core component of the mammalian circadian pacemaker. Science 320: 949-953.

107. Chrousos GP, 1995 The hypothalamic-pituitary-adrenal axis and immune mediated inflammation. N Engl J Med 332: 1351-1362.

108. Ishida A, Mutoh T, Ueyama T, et al, 2005 Light activates the adrenal gland: timing of gene expression and glucocorticoid release. Cell Metab 2: 297-307.

109. Ulrich-Lai YM, Arnhold MM, Engeland WC, 2006 Adrenal splanchnic innervation contributes to the diurnal rhythm of plasma corticosterone in rats by modulating adrenal sensitivity to ACTH. Am J Physiol Regul Integr Comp Physiol 290: R1128-R1135.

110. Balsalobre A, Brown SA, Marcacci L, et al, 2000 Resetting of circadian time in peripheral tissues by glucocorticoid signaling. Science 289: 2344-2347.

111. Yamamoto T, Nakahata Y, Tanaka M, et al, 2005 Acute physical stress elevates mouse period 1 mRNA expression in mouse peripheral tissues via a glucocorticoidresponsive element. J Biol Chem 280: 42036-42043.

112. So AY, Bernal TU, Pillsbury ML, Yamamoto KR, Feldman BJ, 2009 Glucocorticoid regulation of the circadian clock modulates glucose homeostasis.Proc Natl Acad Sci USA 106: 17582-17587.

113. Segall LA, Milet A, Tronche F, Amir S, 2009 Brain glucocorticoid receptors are necessary for the rhythmic expression of the clock protein, PERIOD2, in the central extended amygdala in mice. Neurosci Lett 457: 58-60.

114. Charmandari E, Chrousos GP, Lambrou GI, et al, 2011 Peripheral CLOCK regulates target-tissue glucocorticoid receptor transcriptional activity in a circadian fashion in man. PLoS One 6: e25612.

115. Chrousos GP, Kino T, 2007 Glucocorticoid action networks and complex psychiatric and/or somatic disorders. Stress 10: 213-219.

116. Chrousos GP, Gold PW, 1992 The concepts of stress and stress system disorders. Overview of physical and behavioral homeostasis. JAMA 267: 1244-1252.

117. Antoni FA, 1986 Hypothalamic control of adrenocorticotropin secretion:advances since the discovery of 41-residue corticotropin-releasing factor. Endocr Rev 7: 351-378.

118. Stewart LQ, Roper JA, Young WS, III, O'Carroll AM, Lolait SJ, 2008 Pituitary-adrenal response to acute and repeated mild restraint, forced swim and change in environment stress in arginine vasopressin receptor 1b knockout mice. J Neuroendocrinol 20: 597-605.

119. Bethin KE, Vogt SK, Muglia LJ, 2000 Interleukin-6 is an essential,corticotropin-releasing hormone-independent stimulator of the adrenal axis during immune system activation. Proc Natl Acad Sci U S A 97: 9317-9322.

120. Chrousos GP, 2009 Stress and disorders of the stress system. Nat Rev Endocrinol 5: 374-381.

121. Pervanidou P, Kolaitis G, Charitaki S, et al, 2007 Elevated morning serum interleukin (IL)- 6 or evening salivary cortisol concentrations predict posttraumatic stress disorder in children and adolescents six months after a motor vehicle accident. Psychoneuroendocrinology 32: 991-999.

122. Vgontzas AN, Bixler EO, Lin HM, Prolo P, Trakada G, Chrousos GP, 2005 IL-6 and its circadian secretion in humans. Neuroimmunomodulation 12: 131-140.

123. Vaughan GM, Becker RA, Allen JP, Goodwin CW Jr, Pruitt BA Jr, Mason AD Jr, 1982 Cortisol and corticotrophin in burned patients. J Trauma 22: 263-273.

124. Fish HR, Chernow B, O’Brian JT, 1986 Endocrine and neurophysiologic responses of the pituitary to insulin-induced hypoglycemia: a review. Metabolism 35: 763-780.

125. Udelsman R, Norton JA, Jelenich SE, et al, 1987 Responses of the hypothalamic-pituitary-adrenal and renin-angiotensin axes and the sympathetic system during controlled surgical and anesthetic stress. J Clin Endocrinol Metab 64: 986-994.

126. Luger A, Deuster PA, Kyle SB, et al, 1987 Acute hypothalamic-pituitary adrenal responses to the stress of treadmill exercise. Physiologic adaptations to physical training. N Engl J Med 316: 1309-1315.

127. Raff H, Norton AJ, Flemma RJ, Findling JW, 1987 Inhibition of the adrenocorti-cotropin response to surgery in humans: interaction between dexamethasone 
and fentanyl. J Clin Endocrinol Metab 65: 295-298.

128. Copinschi G, L'Hermite M, Leclercq R, et al, 1975 Effects of glucocorticoids on pituitary hormonal responses to hypoglycemia. Inhibition of prolactin release. J Clin Endocrinol Metab 40: 442-449.

129. Arafah BM, 2006: Hypothalamic pituitary adrenal function during critical illness: limitations of current assessment methods. J Clin Endocrinol Metab 91: 3725-3745.

130. Debono M, Sheppard L, Irving S, et al, 2011 Assessing adrenal status in patients before and immediately after coronary artery bypass graft surgery. Eur J Endocrinol 164: 413-419.

131. Widmer IE, Puder JJ, Konig C, et al, 2005 Cortisol response in relation to the severity of stress and illness. J Clin Endocrinol Metab 90: 4579-4586.

132. Roth-Isigkeit AK, Schmucker P, 1997 Postoperative dissociation of blood levels of cortisol and adrenocorticotropin after coronary artery bypass grafting surgery. Steroids 62: 695-699.

133. Turnbull AV, Rivier CL, 1999 Regulation of the hypothalamic-pituitary-adrenal axis by cytokines: actions and mechanisms of action. Physiol Rev 79: 1-71.

134. Donald RA, Perry EG, Wittert GA, et al, 1993 The plasma ACTH, AVP, CRH and catecholamine responses to conventional and laparoscopic cholecystectomy. Clin Endocrinol (Oxf) 38: 609-615.

135. George JM, Reier CE, Lanese RR, Rower M, 1974 Morphine anesthesia blocks cortisol and growth hormone response to surgical stress in humans. J Clin Endocrinol Metab 38: 736-741.

136. Rittmaster RS, Cutler GB, Jr, et al, 1985 Morphine inhibits the pituitary-adrenal response to ovine corticotropin-releasing hormone in normal subjects. J Clin Endocrinol Metab 60: 891-895.

137. Aizawa T, Yasuda N, Greer MA, 1981 Hypoglycemia stimulates ACTH secretion through a direct effect on the basal hypothalamus. Metabolism 30: 996-1000.

138. Watabe T, Tanaka K, Kumagae M, et al, 1987 Hormonal responses to insulin induced hypoglycemia in man. $\mathrm{J}$ Clin Endocrinol Metab 65:1187-1191.

139. al-Damluji S, 1988 Adrenergic mechanisms in the control of corticotrophin secretion. J Endocrinol 119: 5-14.

140. Jezova D, Kvetnansky R, Kovacs K, Oprsalova Z, Vigas M, Makara GB, 1987 Insulin-induced hypoglycemia activates the release of adrenocorticotropin predominantly via central and propranolol insensitive mechanisms. Endocrinology 120: 409-415.

141. Chen CL, Willis BA, Mooney L, et al, 2010 Cortisol response to individualized graded insulin infusions: a reproducible biomarker for CNS compounds inhibiting HPA activation. Br J Clin Pharmacol 70: 886-894.

142. Streeten DH, Anderson GH, Jr, Dalakos TG, et al, 1984 Normal and abnormal function of the hypothalamicpituitary-adrenocortical system in man. Endocr Rev 5: 371-394.
143. Gadek-Michalska A, Bugajski J, 2004 Role of prostaglandins and nitric oxide in the lipopolysaccharideinduced ACTH and corticosterone response. J Physiol Pharmacol 55: 663-675.

144. Monau TR, Vargas VE, Zhang L, Myers DA, Ducsay CA, 2010 Nitric oxide inhibits ACTH-induced cortisol production in near-term, long-term hypoxic ovine fetal adrenocortical cells. Reprod Sci 17: 955-962.

145. Elander L, Ruud J, Korotkova M, Jakobsson PJ, Blomqvist A, 2010 Cyclooxygenase-1 mediates the immediate corticosterone response to peripheral immune challenge induced by lipopolysaccharide. Neurosci Lett 470: 10-12.

146. Hillhouse EW, 1994 Interleukin-2 stimulates the secretion of arginine vasopressin but not corticotropinreleasing hormone from rat hypothalamic cells in vitro. Brain Res 650: 323-325.

147. Cambronero JC, Rivas FJ, Borrell J, Guaza C, 1992 Interleukin-2 induces corticotropin-releasing hormone release from superfused rat hypothalami: influence of glucocorticoids. Endocrinology 131: 677-683.

148. Arzt E, Stelzer G, Renner U, Lange M, Muller OA, Stalla GK, 1992 Interleukin-2 and interleukin-2 receptor expression in human corticotrophic adenoma and murine pituitary cell cultures. J Clin Invest 90: 1944-1951.

149. Bateman A, Singh A, Kral T, Solomon S, 1989 The immune-hypothalamic pituitary-adrenal axis. Endocr Rev 10: 92-112.

150. Rettori V, Milenkovic L, Beutler BA, McCann SM, 1989 Hypothalamic action of cachectin to alter pituitary hormone release. Brain Res Bull 23: 471-475.

151. Chesnokova V, Auernhammer CJ, Melmed S, 1998 Murine leukemia inhibitory factor gene disruption attenuates the hypothalamo-pituitary-adrenal axis stress response. Endocrinology 139: 2209-2216.

152. Auernhammer CJ, Chesnokova V, Bousquet C, Melmed S, 1998 Pituitary corticotroph SOCS-3: novel intracellular regulation of leukemia-inhibitory factor-mediated proopiomelanocortin gene expression and adrenocorticotropin secretion. Mol Endocrinol12: 954-961.

153. Rivier CL, Grigoriadis DE, Rivier JE, 2003 Role of corticotropin-releasing factor receptors type 1 and 2 in modulating the rat adrenocorticotropin response to stressors. Endocrinology 144: 2396-2403.

154. Chesnokova V, Kariagina A, Melmed S, 2002 Opposing effects of pituitary leukemia inhibitory factor and SOCS-3 on the ACTH axis response to inflammation. Am J Physiol Endocrinol Metab 282: E1110-E1118.

155. Chesnokova V, Melmed S, 2000 Leukemia inhibitory factor mediates the hypothalamic pituitary adrenal axis response to inflammation. Endocrinology 141: 4032-4040.

156. Kariagina A, Romanenko D, Ren SG, Chesnokova V, 2004 Hypothalamic pituitary cytokine network. Endocrinology 145: 104-112.

157. Vermes I, Beishuizen A, Hampsink RM, Haanen C, 
1995 Dissociation of plasma adrenocorticotropin and cortisol levels in critically ill patients: possible role of endothelin and atrial natriuretic hormone. J Clin Endocrinol Metab 80: 1238-1242.

158. Marik PE, 2009 Critical illness-related corticosteroid insufficiency. Chest 135: 181-193.

159. Cooper MS, Stewart PM, 2003 Corticosteroid insufficiency in acutely ill patients. N Engl J Med 348: 727-734.

160. Bornstein SR, 2009 Predisposing factors for adrenal insufficiency. N Engl J Med 360: 2328-2339.

161. Bornstein SR, Engeland WC, Ehrhart-Bornstein M, Herman JP, 2008 Dissociation of ACTH and glucocorticoids. Trends Endocrinol Metab 19: 175-180.

162. Charmandari E, Kino T, Ichijo T, Chrousos GP, 2008 Generalized glucocorticoid resistance: clinical aspects, molecular mechanisms, and implications of a rare genetic disorder. J Clin Endocrinol Metab 93: 1563-1572.

163. Arlt W, Hammer F, Sanning P, et al, 2006 Dissociation of serum dehydroepi-androsterone and dehydroepiandrosterone sulfate in septic shock. J Clin Endocrinol Metab 91: 2548-2554.

164. Sam S, Corbridge TC, Mokhlesi B, Comellas AP, Molitch ME, 2004 Cortisol levels and mortality in severe sepsis. Clin Endocrinol (Oxf) 60: 29-35.

165. Annane D, Sebille V, Troche G, Raphael JC, Gajdos P, Bellissant E, 2000 A 3-level prognostic classification in septic shock based on cortisol levels and cortisol response to corticotropin. JAMA 283: 1038-1045.

166. Sprung CL, Annane D, Keh D, et al, 2008 Hydrocortisone therapy for patients with septic shock. N Engl J Med 358: 111-124.

167. Mastorakos G, Ilias I, 2003 Maternal and fetal hypothalamic-pituitary-adrenal axes during pregnancy and postpartum. Ann N Y Acad Sci 997: 136-149.

168. Charmandari E, Kino T, Souvatzoglou E, Chrousos GP, 2003 Pediatric stress: hormonal mediators and human development. Horm Res 59: 161-179.

169. Vgontzas AN, Papanicolaou DA, Bixler EO, et al, 2000 Sleep apnea and daytime sleepiness and fatigue: relation to visceral obesity, insulin resistance, and hypercytokinemia. J Clin Endocrinol Metab 85: 1151-1158.

170. Tsigos C, Chrousos GP, 2006 Stress, obesity, and the metabolic syndrome: soul and metabolism. Ann N Y Acad Sci 1083: xi-xiii.

171. Chrousos GP, 2000 The role of stress and the hypothalamic-pituitary-adrenal axis in the pathogenesis of the metabolic syndrome: neuro-endocrine and target tissue-related causes. Int J Obes Relat Metab Disord 24: Suppl 2: 50-55.

172. Trayhurn P, Wood IS, 2004 Adipokines: inflammation and the pleiotropic role of white adipose tissue. Br J Nutr 92: 347-355.

173. Hotamisligil GS, Spiegelman BM, 1994 Tumor necrosis factor alpha: a key component of the obesity-diabetes link. Diabetes 43: 1271-1278.
174. Kazakou P, Kyriazopoulou V, Michalaki M, Ierodiakonou V, Psyrogiannis A, Habeos I, 2012 Activated hypothalamic pituitary adrenal axis in patients with metabolic syndrome. Horm Metab Res 44: 839-844.

175. Kyrou I, Tsigos C, 2008 Chronic stress, visceral obesity and gonadal dysfunction. Hormones (Athens) 7: 287-293.

176. Moutsatsou P, Kassi E, Papavassiliou AG, 2012 Glucocorticoid receptor signaling in bone cells. Trends Mol Med 18: 348-359.

177. Elenkov IJ, Chrousos GP, 1999 Stress Hormones, Th1/ Th2 patterns, Pro/Anti-inflammatory Cytokines and Susceptibility to Disease. Trends Endocrinol Metab 10: 359-368.

178. Elenkov IJ, Chrousos GP, 2006 Stress system-organization, physiology and immunoregulation. Neuroimmunomodulation 13: 257-267.

179. Papadopoulos AS, Cleare AJ, 2012 Hypothalamicpituitary-adrenal axis dysfunction in chronic fatigue syndrome. Nat Rev Endocrinol 8: 22-32.

180. Tzioufas AG, Tsonis J, Moutsopoulos HM, 2008 Neuroendocrine dysfunction in Sjogren's syndrome. Neuroimmunomodulation 15: 37-45.

181. Tak LM, Cleare AJ, Ormel J, et al, 2011 Meta-analysis and meta-regression of hypothalamic-pituitary-adrenal axis activity in functional somatic disorders. Biol Psychol 87: 183-194.

182. Joseph-Vanderpool JR, Rosenthal NE, Chrousos GP, et al, 1991 Abnormal pituitary-adrenal responses to corticotropin-releasing hormone in patients with seasonal affective disorder: clinical and pathophysiological implications. J Clin Endocrinol Metab 72: 1382-1387.

183. Demitrack MA, Dale JK, Straus SE, et al, 1991 Evidence for impaired activation of the hypothalamicpituitary-adrenal axis in patients with chronic fatigue syndrome. J Clin Endocrinol Metab 73: 1224-1234.

184. Geiss A, Rohleder N, Anton F, 2012 Evidence for an association between an enhanced reactivity of interleukin-6 levels and reduced glucocorticoid sensitivity in patients with fibromyalgia. Psychoneuroendocrinology 37: 671-684.

185. O'Keane V, Lightman S, Patrick K, et al, 2011 Changes in the maternal hypothalamic-pituitary-adrenal axis during the early puerperium may be related to the postpartum ‘blues'. J Neuroendocrinol 23: 1149-1155.

186. Schmidt-Reinwald A, Pruessner JC, Hellhammer DH, et al, 1999 The cortisol response to awakening in relation to different challenge tests and a 12-hour cortisol rhythm. Life Sci 64: 1653-1660.

187. Kirschbaum C, Pirke KM, Hellhammer DH, 1993 The 'Trier Social Stress Test'-a tool for investigating psychobiological stress responses in a laboratory setting. Neuropsychobiology 28: 76-81.

188. Kudielka BM, Kirschbaum C, 2003 Awakening cortisol responses are influenced by health status and awakening time but not by menstrual cycle phase. 
Psychoneuroendocrinology 28: 35-47.

189. Kudielka BM, Wust S, 2010 Human models in acute and chronic stress: assessing determinants of individual hypothalamus-pituitary-adrenal axis activity and reactivity. Stress 13: 1-14.

190. Oki Y, Peatman TW, Qu ZC, Orth DN, 1991 Effects of intracellular $\mathrm{Ca} 2+$ depletion and glucocorticoid on stimulated adrenocorticotropin release by rat anterior pituitary cells in a microperifusion system. Endocrinology 128: 1589-1596.

191. Holmes MC, Catt KJ, Aguilera G, 1987 Involvement of vasopressin in the down-regulation of pituitary corticotropin-releasing factor receptors after adrenalectomy. Endocrinology 121: 2093-2098.

192. Luo X, Kiss A, Rabadan-Diehl C, Aguilera G, 1995 Regulation of hypothalamic and pituitary corticotropinreleasing hormone receptor messenger ribonucleic acid by adrenalectomy and glucocorticoids. Endocrinology 136: 3877-3883.

193. Martens C, Bilodeau S, Maira M, Gauthier Y, Drouin J, 2005 Protein-protein interactions and transcriptional antagonism between the subfamily of NGFI-B/Nur77 orphan nuclear receptors and glucocorticoid receptor. Mol Endocrinol 19: 885-897.

194. Dostert A, Heinzel T, 2004 Negative glucocorticoid receptor response elements and their role in glucocorticoid action. Curr Pharm Des 10: 2807-2816.

195. Davis LG, Arentzen R, Reid JM, et al, 1986 Glucocorticoid sensitivity of vasopressin mRNA levels in the paraventricular nucleus of the rat. Proc Natl Acad Sci U S A 83: 1145-1149.

196. Itoi K, Mouri T, Takahashi K, et al, 1987 Suppression by glucocorticoid of th immunoreactivity of corticotropin- releasing factor and vasopressin in the paraventricular nucleus of rat hypothalamus. Neurosci Lett 73: 231-236.

197. Ma XM, Aguilera G, 1999 Differential regulation of corticotrophin releasing hormone and vasopressin transcription by glucocorticoids. Endocrinology 140: 5642-5650.

198. Drouin J, Maira M, Philips A, 1998 Novel mechanism of action for Nur77 and antagonism by glucocorticoids: a convergent mechanism for $\mathrm{CRH}$ activation and glucocorticoid repression of POMC gene transcription. $\mathrm{J}$ Steroid Biochem Mol Biol 65: 59-63.

199. Muglia LJ, Jacobson L, Luedke C, et al, 2000 Corticotropin-releasing hormone links pituitary adrenocorticotropin gene expression and release during adrenal insufficiency. J Clin Invest 105: 1269-1277.

200. Connelly MA, 2009 SR-BI-mediated HDL cholesteryl ester delivery in the adrenal gland. Mol Cell Endocrinol 300: 83-88.

201. Mavridou S, Venihaki M, Rassouli O, et al, 2010 Feedback inhibition of human scavenger receptor class B type I gene expression by glucocorticoid in adrenal and ovarian cells. Endocrinology 151: 3214-3224.

202. Keller-Wood ME, Dallman MF, 1984 Corticosteroid inhibition of ACTH secretion. Endocr Rev 5: 1-24.

203. Evanson NK, Tasker JG, Hill MN, Hillard CJ, Herman JP, 2010 Fast feedback inhibition of the HPA axis by glucocorticoids is mediated by endocannabinoid signaling. Endocrinology 151: 4811-4819.

204. Rosenfield RL, Helke J, Lucky AW, 1985 Dexamethasone preparation does not alter corticoid and androgen responses to adrenocorticotropin. J Clin Endocrinol Metab 60: 585-589. 